\title{
VARIA:
}

\section{Gerta Figulusová - „dcera českého národa“ z rodu Komenského: životní př́běh pohledem komeniologie}

\author{
Markéta PÁNKOVÁa
}

a Národní pedagogické muzeum a knihovna J. A. Komenského, Praha, Česká republika

Když se hovoří nebo píše o J. A. Komenském, jedné z největších osobností české kultury, veřejnost se často zajímá i o to, zda dosud žijí jeho potomci. Zejména po vzniku samostatného Československa odkaz osobnosti Komenského pozitivně posílil utváření českého národního povědomí, jak dokládá řada známých fakti̊ (počínaje vytvořením portrétů, soch či medailí ztvárňujících Komenského, konče výstavbou pomníků, vydáváním knih o Komenském nebo pojmenováním ulic či škol).

A proto, když 14. srpna 2018 pravnučka Karla Carmineho paní Jarmila Vaňková zapůjčila Národnímu pedagogickému muzeu a knihovně J. A. Komenského korespondenci rodiny Figulů a publikaci o J. V. Figulovi doplněnou o fotografie a dobový tisk, netušila, že díky těmto dokumentům dokáže zaplnit bílé místo v životě Gerty Figulusové, př́ímé potomkyně J. A. Komenského, a jejího otce. Neprobádána zůstala totiž doba, kdy Gerta žila v Praze u své poručnice Marie Carmineové, manželky Karla Carmineho (1869-1937). ${ }^{1}$ Gerta Figulusová, jediná dcera Jiř́iho Viktora Figula (1858-1927), se narodila dne 22. 12. 1912 ve městě Roiberg (Randgate), Trasvaal v Jižní Africe a zemřela dne 18. 8. 1997 v Glendale v Kalifornii (USA). Rodina Carmineho, která se o Gertu mohla postarat, byla finančně zaopatřená; K. Carmine dlouho působil v Živnostenské bance v Praze jako ředitel osobního oddělení a od roku 1919 ve funkci náměstka ředitele. Angažoval se také na poli kulturním, sociálním i hospodářském.

Otec Gerty, J. V. Figulus, se v Jižní Africe stal technikem v transvaalských dolech, později vykonával různá povolání v transvaalských závodech. Jeho dcera Gerta zde získala vzdělání v angličtině, holandštině a němčině a ovládala i domorodý jazyk zulu. Figulus se stále hlásil k českým kořenům, také jeho otec dr. Theodor Figulus (1813-1871), který se stal lékařem ve Frankensteinu, mu často připomínal: „Wir sind eigentlich Böhmen“. Proto po obdržení zprávy o vzniku Československé republiky v roce 1918, kdy její první prezident ve svém prvním projevu použil Komenského prorocká slova, že (...), ,vláda věcí tvých k tobě se zase navrátí, ólide český", napsal zprávu výboru Československého národního sdružení v Johannesburgu (čeští krajané žijící v Jižní Africe), že si činí nárok na to být posledním

\footnotetext{
1 Narozen 19. 2. 1869 v Řečanech nad Labem, zemřel 20. 5. 1937 v Praze. Správnost dalších údajů o p. Carmineovi potvrdil PhDr. Jakub Kunert, hlavní archivář ČNB.
} 
mužským potomkem Komenského. Díky tomuto sdružení byl Figulus objeven pro Československo, kde o něm začaly psát noviny prostřednictvím člena Národní rady československé (NRČ) Karla A. Červenky. Články vyvolávaly velký zájem nejen v Čechách, ale i v cizině. Zájem o Komenského potomky zesílil i po oslavách 250. výročí úmrtí J. A. Komenského v roce 1920. Figulus prijel s Gertou do Československa dne 20. června 1921, aby konečně navštívili zemi, odkud pocházel jejich předek - Jan Amos Komenský. Cílem jejich návštěvy se stala Praha, kde chtěl J. V. Figulus navázat kontakty s politickými a kulturními představiteli a najít možnost dalšího vzdělání pro svou dceru ve vlasti svých předků. Rovněž chtěl navštívit místa spojená s životem Komenského. Do Prahy přijeli v předvečer 300. výročí popravy dvaceti sedmi představitelů českých stavů na Staroměstském náměstí. Člen NČR Augustin Seifert o této návštěvě podává svědectví ve svém nekrologu $Z a$ Jiřim Figulusem otištěném ve sborníku Naše zahraničí v prosinci 1927. Především vzpomíná na první setkání s potomkem Komenského, šedesáti tříletým mužem, a jeho devítiletou dcerou, kteří neváhali urazit téměř $12.000 \mathrm{~km}$, aby se zúčastnili připomínkové akce $\mathrm{k}$ Bílé hoře. Vzácná návštěva byla tehdy přijata předsedou Národní československé rady Adolfem Prokůpkem. J. V. Figulus zaznamenal do pamětní knihy NČR setkání takto: „Ač narozen v Pruském Slezsku, považoval jsem se vždy za Čecha jako můj zesnulý otec za potomka rodiny české. A tento vnitřni hlas krve mě přměl, že jsem přijel spatřit Čechy po 41 letech, prožitých v Jižni Africe, navštívit vlast svého velikého předka, na kterého jsem právem hrdý, a abych byl př́tomen památné oslavě ukrutně popravených českých vi̊dců před 300 lety. Komenský prorokoval, odešed raději do vyhnanství, nežli by zůstal pode jhem utiskovatelư, kteři potlačovali svobodu českého národa, - že opět zasvitne den, kdy český národ znovu nabyde svobody a volnosti - a jeho proroctvi se právě splnilo. Přivedl jsem své jediné dítě Gertu, aby byla vychována $v$ duchu a jazykem svého předka. V̌̃em krajanům volám Na zdar! ${ }^{2} \mathrm{~V}$ Praze se jim dostalo vysokých poct od Českobratrské církve evangelické a politických a kulturních osobností. Dne 13. října 1921 byli rovněž přijati na Pražském hradě prvním prezidentem Československé republiky T. G. Masarykem. ${ }^{3}$ Gerta byla v Praze nazývána „dcerou národa““. Hodnotíme-li návštěvu potomků Komenského v době, kdy Československo usilovalo o posílení národního povědomí, jejich přítomnost tomu jistě přispěla. S tím souvisela i snaha co nejlépe finančně a kulturně podporovat poslední potomkyni Komenského.

Po svém prŕíjezdu do Československa se J. V. Figulus dostal pod ochranu NRČ. Marie Carmineová (rozená Boučková [1872-1956]) ${ }^{4}$ byla ustanovena jako poručnice Gerty, jak je potvrzeno zápisem z jednání NČR. ${ }^{5} \mathrm{M}$. Carmineová měla velkou podporu ve svém manželovi, nebot' byl aktivním členem Národní rady československé v Praze, která měla za cíl pečovat o české, př́ípadně slovenské menšiny v jazykově smíšených pohraničních oblastech, ale i o české a slovenské menšiny v zahraničí a informovat je o životě v českých zemích.

\footnotetext{
${ }^{2}$ SEIFERT, Augustin, 1927. Za Jiřím Figulusem. In: Sborník NRČ Naše zahraničí. Roč. VIII, sv. 4, s. 1 (článek Seiferta je svázaný v knize Arnošta Polavského J. V. Figulus a jeho africká dobrodružství vydané v Praze roku 1928).

${ }^{3}$ SEIFERT, Augustin, 1927. Za Jiřím Figulusem. In: Sborník NRČ Naše zahraničí. Roč. VIII, sv. 4, s. 4.

${ }^{4}$ Děti: Miroslav (nar. 5. 10. 1896) a Libuše (nar. 16. 5. 1902).

${ }^{5}$ SEIFERT, Augustin, 1927. Za Jiřím Figulusem. In: Sbornik NRČ Naše zahraničí. Roč. VIII, sv. 4, s. 8.
} 
Jiř́i V. Figulus se rozhodl vrátit zpět do Jižní Afriky v lednu 1922, dceru však nechal u poručníků v Čechách, kde měla získat vzdělání na českých školách. Před svým odjezdem dne 4. října 1921 Gertu zapsal do II. třídy české dívčí Obecné školy u sv. Kř̌žze Většího v Praze $1^{6}$, a tím mohla Gerta navázat na dvě třídy absolvované v anglické, později holandské škole v Jižní Africe. Česká zemská komise pro péči o mládež v Praze přidělila Gertě vychovatelský príspěvek. Gerta stále udržovala písemný styk se svou matkou, Annou Figulusovou, která zůstala v Jižní Africe. Důvod, proč zůstala matka Gerty sama v Jižní Africe, nechtěla Gerta sdělit ani v pozdějších letech svým dětem.

V době, kdy poměry v Jižní Africe nebyly pro Figula přijatelné, se dne 19. prosince 1922 vrátil zpět do Československa, kde mu byl ministrem obchodu nabídnut post konzula při úřadu pro zahraniční obchod. ${ }^{7}$ Po půl roce mu obec pražská přislíbila domovské právo a v r. 1924 změnil Figulus potřetí ve svém životě příslušnost (německou, anglickou) a stal se i s dcerou státním občanem Československé republiky. Velmi se snažil naučit se česky. Jako konzul se velmi osvědčil, jakmile se v zahraničních časopisech, zejména holandských nebo anglických, objevila nějaká „nesprávná“ informace o Československu nebo dokonce pomluva, napsal ihned těmto listům opravné články a tím čelil „,nepřátelským zprávám““. ${ }^{8}$ Bohužel při cestách po Čechách a Moravě, které vedly do míst spojených s životem Komenského (Olomouc, Přerov, Nivnice, Luhačovice, naposledy navštívil Uherský Brod), onemocněl a nečekaně zemřel 27. července 1927. Jeho rakev byla vystavena v českobratrském kostele sv. Martina ve zdi v centru Prahy. Obrovský zájem o pohřeb Figula tkvěl i v tom, že v něm viděli ztělesněný symbol českého národního osudu. Historik, komeniolog a autor prvního rodokmenu Komenského Jiř́i Václav Klíma (1874-1948) ${ }^{9}$ se vyjádřil před rakví: „Tento potomek z krve Komenského se nejen dočkal splnění slov ,Kšaftu', ale pochopiv také, jak se naplnil osud, podal pres staletí ruku svému velikému předku (...). “10 Prezident T. G. Masaryk $\mathrm{k}$ poctě potomka Komenského věnoval nádherný věnec, po stranách stála čestná stráž pražského Sokola, nebot' Figulus byl jejich členem.

Figulus rovněž chránil rodinnou památku - diamantový prsten, který Komenský věnoval své dceři Alžbětě při svatbě s Petrem Figulem. Původně měl prsten připadnout synovi bratra J. V. Figula - Maxi Figulovi, avšak ten padl za první světové války. J. V. Figulus se dohodl s NRČ, že pokud zemře, prsten bude chránit do dovršení Gertiných dvacátých narozenin. V každém př́ípadě měl (podle závěti Figula) zůstat navždy v Československu, což se, jak je známo, nestalo. Nyní jej vlastní Jan F. Kallik žijící v USA. ${ }^{11}$

\footnotetext{
${ }^{6}$ Budova školy slouží až do dnešní doby (ZŠ Curie, Praha 1).

${ }^{7}$ Nebyl velvyslancem, jak se ve svých pamětech zmiňuje Jan Ferdinand Kallik - jeho vnuk.

${ }^{8}$ POLAVSKÝ, Arnošt, 1928. J. V. Figulus a jeho africká dobrodružství. Praha, s. 163.

9 Jako uznávaný komeniolog byl mj. jednatelem Spolku pro postavení pomníku J. A. Komenskému $v$ Amsterodamu. Aktivně působil i ve vzdělávacím odboru Československé obce sokolské.

${ }^{10}$ POLAVSKÝ, Arnošt, 1928. J. V. Figulus a jeho africká dobrodružství. Praha, s. 164.

${ }^{11}$ Více se lze dozvědět o prstenu v knize od Markéty Pánkové Jan Amos Komenský v českém a světovém umění (1642-2016), vydané v Praze roku 2017 (s. 31).
} 
Dochovaly se i doklady o stálých kontaktech rodiny Figulů, a to díky korespondenci, která zůstala zachována díky Carmineho rodině. ${ }^{12}$ Po smrti Gertina otce J. V. Figula v r. 1927 však počáteční nadšení a pozornost věnovaná potomkům Komenského postupně slábly. Gerta zůstala v Československu sama. Podle poručnice Marie Carmineové měla Gerta nejprve zůstat v Pöttingeu v Olomouci, aby si doplnila všeobecné vzdělání na měšt'anské dívčí škole. ${ }^{13}$ Rodiče sledovali v rámci písemného styku, jak se jí daří v české škole. Např. dne 22. března 1922 napsala matka dceři a nabádala ji, aby se ve škole dobře učila. ${ }^{14}$ Po návštěvě vzdělávacího ústavu v Olomouci pokračovala Gerta ve studiu v Praze na škole pro ženská povolání. V Praze pak absolvovala s vyznamenáním Ústav ku vzdélání učitelek domácích nauk při Státním ženském ústavu učitelském.

V pražském českobratrském sboru poznala Ferdinanda Kallika (1912-1984), svého budoucího manžela, pozdějšího pražského architekta a malíře. ${ }^{15} \mathrm{O}$ tom, že Gerta byla přijata do rodiny Karla Carmineho a strávila zde i Vánoce v r. 1927, svědčí zápis v rodinné kronice. Zachovaly se výstřrižky časopisů Naše zahraničí které byly vkládány K. Carminem do knihy Arnošta Polavského: Jiři Viktor Figulus a jeho africká dobrodružství. ${ }^{16}$ Vzácné jsou fotografie a korespondence mezi Jiřím V. Figulem, Gertou a její matkou Annou žijící v té době $\mathrm{v}$ Johannesburgu. Ty jsou uschovány $\mathrm{v}$ rodinném archivu rodiny Vaňkových $\mathrm{v}$ Praze.

\footnotetext{
${ }^{12}$ K. Carmine byl mj. dlouholetým členem Obce sokolské, o čemž svědčí i jeho sportovní aktivity. Jednou z jeho nesporně největších zásluh bylo i to, že se v roku 1910 stal iniciátorem založení Klubu úředníkủ živnostenské banky, který se stal významnou platformou pro úředníky banky v oblasti zájmové i zaměstnanecké a dva roky byl jeho předsedou. Klub vydával časopis Věstník klubu úředniki̊ Živnostenské banky.

${ }^{13}$ Pöttingeum bylo postaveno v letech 1894-1895 za účelem sídla Ústavu hraběte Pöttinga pro výchovu dívek, což byla první olomoucká škola pro ženská povolání s českým vyučovacím jazykem. Budova školy je zachována a slouží i dnes vzdělávacímu účelu. Od roku 1997 nese název Střední zdravotnická škola a Vyšši odborná škola zdravotnická Emanuela Pöttinga.

${ }^{14}$ Překlad dopisu z angličtiny ze dne 2 března 1922, P.O. Box 1509, Johannesburg:

Moje milé dítě!

Jen pár řádků, abys věděla, že se mám docela dobře, a doufám, že i ty mi napíšeš to samé.

Věrím, že jsi poslušné ditě a že se dobře učišs. Mám tě moc ráda, posilám ti mnoho hubiček a doufám, že tě brzy zase někdy uvidím. Vyřid' mé nejsrdečnějši pozdravy paní Carmine a její rodině; a poděkuj jí za mě za všechnu laskavost, kterou ti prokazuje.

Sbohem Gerti, Bůh ti žehnej

Tvá milující matka

Anna Figulus

(rukou otce dopsáno - s chybami)

Mila Gerta.

V upominku spozdravem vás.
}

Nazdar!

Vas otěc J. Victor Figulus. se hubičku.

${ }^{15}$ Po sňatku Gerty s Ferdinandem Kallikem v Praze se v roce 1939 narodil syn Jan Ferdinand a v roce 1944 dcera Jarmila Daniela. Po druhé světové válce, v roce 1947, za podpory československé a holandské vlády, odjeli Kallikovi do Jižní Afriky k nemocné matce Anně Figulusové. Po matčině smrti a po třinácti letech pobytu v Jižní Africe se přestěhovali do Kanady a pak do USA, kde se usídlili v Kalifornii. Když v r. 1984 zemřel její manžel, Gerta žila až do své smrti v městě Glendale, kde dodnes žije její syn Jan Ferdinand Kallik s rodinou (desátá generace). Jan je rovněž držitelem rodinného diamantového prstenu. V současné době o něm však nechce hovořit.

${ }^{16}$ POLAVSKÝ, Arnošt, 1928. Jiř́ Viktor Figulus a jeho africká dobrodružství. Praha. 
Kopie rodinné kroniky a korespondence jsou uloženy v Národním pedagogickém muzeu a knihovně J. A. Komenského. Konkrétně byly z rodinného archivu zapůjčeny a zdigitalizovány tyto dokumenty:

1) Rukopis Zápisník pro Domeček v Řevnicích od 16. záŕí 1928, vázaný v modrém plátně.

2) Deník dítěte, zapisování započato 27. 5. 1924, vázaný v zelené kůži.

3) Rukopis Kronika naši rodiny. Kniha druhá, zapisování započato v dubnu 1927, vázáno v béžovém plátně, na předních deskách nápis Kronika naši rodiny a obrázek domu.

4) Dopis J. V. Figula paní Carmineové z 21. 12. 1921.

5) Obálka s vizitkou J. V. Figula a lístkem z rostliny s nápisem Souvenir from South Africa on bouard S. S. Goorkha at sea.

\section{3/1/22 Victor Figulus a S pozdravem Miss Carmine}

6) Pohlednice nákladem Ženského obzoru: Vzkř̌̌šení národa českého. Republikánský plakát svobody na počest presidenta T. G. Masaryka. (vyobrazení héroa s československou vlajkou a lvem u nohou, na schodišti tesáno datum 28/X 1918); na rubu podpis J. V. Figula.

7) Pohlednice s vyobrazením zámku Frankenstein, pohlednice je adresována Gertě Figulusové, podepsaná otcem J. V. Figulem a matkou Annou (pozn. autorky: ve Frankensteinu žil otec J. V. Figula).

8) Dopis Anny Figulusové s př́ípiskem J. V. Figula jejich dceři Gertě z 22. 3. 1922.

Uvedených osm dokumentů bylo fyzicky vystaveno ${ }^{17}$ na mezinárodní výstavě s názvem Historické portréty Jana Amose Komenského a jeho současnikiù, která byla veřejnosti zpř́istupněna od května do listopadu 2019 v Národním pedagogickém muzeu a knihovně J. A. Komenského ve Valdštejnské ulici v Praze $1 .{ }^{18}$ Kopie některých dokumentů jsou též využívány ve stálé expozici Odkaz Komenského. Tradice a výzvy české vzdélanosti Evropě.

V listopadu 2019 Markéta Pánková a Petr Šolar navštívili rodinu Jana F. Kallika (se souhlasem manželů Kallikových) a natočili pro následující generace dokumentární film, jehož obsahem jsou vzpomínky jednotlivých členů rodiny. Nejdůležitější pro tento příspěvek jsou

\footnotetext{
${ }^{17}$ Všechny předměty jsou v dobrém fyzickém stavu a před vystavením nepotřebovaly žádné restaurování. To dokládá, $\mathrm{s}$ jako péćí byly dlouhodobě uchovávány u potomků rodiny Carmineových pro další generace.

${ }^{18}$ Výstava představila portréty J. A. Komenského, jeho potomků, spolupracovníků. Na výstavě byly také prezentovány drobné předměty spjaté s připomínkou památky Učitele národů: pamětní medaile a odznaky, bankovky, poštovní známky nebo školní rozvrhy hodin. K raritám výstavy patřil kolek (známka) Matice vyššího vzdělání v Iowě, jehož koupí se přispívalo do fondu na podporu českých studentů v USA a na výuku českého jazyka za oceánem. K vidění byly i doklady, které pocházely ze soukromých sbírek rodiny poručníkủ Gerty Kallikové, dcery J. V. Figula (z 8. generace potomků J. A. Komenského), během jejího pobytu v Československu. Výstava vznikla spoluprací NPMK, Oblastního muzea v Lešně a Polského institutu v Praze. Zápůjčkami se na výstavě podílely Poštovní muzeum, Národní muzeum a soukromé osoby.

Těmito událostmi se slavnostně zahájily Národní oslavy výročí Učitele národů: 350. výročí úmrtí (2020) a 430. výročí jeho narození (2022). Veřejnosti se nová výstava NPMK otevřela 17. května a trvala do 1. prosince 2019.
} 
vzpomínky Jana F. Kallika na matku. ${ }^{19}$ Vzpomínal na své předky, zejména na svého dědečka J. V. Figula a matku Gertu Figulusovou. Jeho vzpomínky nám doplňují již dříve známá fakta o Gertě a jejím otci J. V. Figulovi a jeho plánech na vzdělávání své dcery. V tomto příspěvku jsou níže uvedeny vzpomínky, které se vážou ke vzdělávání a pobytu Gerty a jejího otce v Jižní Africe a Československu.

Jan F. Kallik vzpomíná: „Myslím, že bych měl začít s nastíněním toho, jak se naše rodina dostala do Jižni Afriky. A to zapř́činil můj dědeček Jiři Figulus - ten byl čtvrtým synem rodiny, tedy šlechtické rodiny v Německu. Takže se dělo to, že první syn po smrti otce zdědil všechno, druhý syn se stal ministrem, třetí syn šel do armády a čtvrtý syn nikoho nezajímal. Můj dědeček byl tím čtvrtým synem, tak se stal inženýrem a získal práci na Novém Zélandu. Nalodil se a vyrazil do Kapského Města. Kapské město je obklopené velmi bouřlivým mořem a jejich lod'se začala potápět. Jela s ní ale druhá lod', která miŕila do Austrálie, a vyzvedla je, avšak i ona se začala potápět. Nakonec připlula třetí lod', vzala všechny na palubu a přistála v Kapském městě. (...)

Abyste rozuméli, tohle je pouze rodinná historie a nevím, jestli je to přesné. Ale, víte, zdá se, že je v tom všem trocha pravdy. Nakonec tedy přistál (pozn. J. V. Figulus) v Kapském Městě a lod' už dál neplula. Vracela se do Anglie. Takže se stal jedním z lidí, jedním z raných osadniků v Jižni Africe. Patřil ke šlechtě a viděl jsem jeho fotky s lidmi, kteři přijeli do Jižní Afriky a měli fotoaparát. Jako oranžský princ - on, jeho dva společníci a můj dědeček jsou vyfocení spolu. Stal se tedy místním zastupitelem, byl inženýrem, byl manažerem farem, fušoval do všeho. No, přišla búrská válka a on jako Němec neměl př́liš v lásce Angličany, takže bojoval s Búry proti Angličanům. A měl na starosti jedno z mála děl, které Búrové mèli. Vite, pak válka skončila, a než se nadáli, přišla první světová válka. Byl Němec, ale považoval se za Jihoafričana, takže se pridal k Jihoafričanům v boji proti Němcům. Jak vidite, měl velmi pestrýživot. Pak ve věku... myslím, že mu bylo přes padesát let, a stalo se to, že mu jeho otec (pozn. Theodor Figulus) napsal dopis, v němž stálo: ,Tví tři starší bratři nemaji děti, koukej si někoho vzit! Potřebujeme děti! 'Takže pak si vzal mou babičku, která byla velmi mladá a také Němka. A než se nadáli, narodila se moje matka. Takže tam potom zůstali a dodnes si nejsem úplně jistý, ale myslím, že ho pozvala česká vláda, aby prijel do Československa, nebo možná plnil reprezentačni funkci na cestě do Československa a Německa. Moje matka vždycky ríkala, že byl vyslancem Jižni Afriky, a nejspiš jím byl, protože si nemyslím, že tam měli jiného vyslance. Nicméně mnoho z těchto př́běhů mi vyprávěla má matka a samozřejmě jí bylo pouze kolem 15 let, když zemřel. Takže si nejsem jistý, jestli jsou všechny ty př́běhy přesné, a rozhodně jich není mnoho. V Jižni Africe byl tedy ve styku s mnoha velmi důležitými lidmi ve vládě, jako byl Jan Smuts - ten byl jedním z jeho prátel. Ale potom se dostal do Československa - jen on a má matka. Vážně nechápu, pročs nimi nejela moje babička, ale mé matce bylo pouze kolem 15 let, když zemřel. A stala se svěřenkyní státu. Proč se nevrátila do Jižni Afriky, kde měla matku, nevím. Byla vždy velmi opatrná, když nám tohle vyprávěla nechci ř́ct prímo tajnůstkářská, ale měla takové sklony. Nakonec si vzala mého otce. A potom, víte, můj otec byl opravdu... už na začátku druhé světové války se chtěl přestěhovat

\footnotetext{
${ }^{19} \mathrm{~V}$ prosinci 2019 oslavil ve svém domě se svou rodinou osmdesát let.
} 
do Jižní Afriky, ale rodina mu řekla: ,Ne, to nemůžeš. Máš továrnu, jsi nejstarší syn. Musišs vést továrnu a nic se nestane. 'No, Německo zahájilo okupaci a zůstali jsme tu ${ }^{20}$ po celou válku. Ale po válce můj otec znovu řekl: „Nelíbí se mi komunisté. 'A tentokrát už své rodině nenaslouchal a odjeli jsme."

A na otázku, zda byl v nějaké škole v Praze, odpovídá:

„Ano. Ano. Pravděpodobně asi jeden rok. Ano, tohle jsem zapomněl. Ano, pamatuji si docela dost. A potom, víte, předtím, než jsme odjeli do Jižní Afriky, můj otec s námi nemohl jet. Moje matka se tam narodila, takže diky tomu jsme ona, má sestra a já mohli jet do Jižní Afriky, měli jsme všechny pasy a podobně. Mého otce tehdy nechtěli pustit. Hranice se zavíraly. A kvůli tomu se nemohl dostat z Československa. Takže nakonec byly potřeba tři povolení a oni mu vždycky dali dvě, ale ne to třetí. Nakonec udělali chybu, dali mu dvě, ale výsledkem bylo, že nemohl vystoupit z letadla po celou cestu. Takže byl v Portugalsku a dva týdny musel zůstat v letadle, protože nesměl vystoupit. Nakonec jsme byli na zaoceánské lodi a ta plula z Amsterodamu do Jižní Afriky. A nebylo tam moc jídla, všechno jim došlo - došel jim cukr, došlo jim všechno. A vy se mě ptáte, vite, jestli jsem měl problém s angličtinou? To byla jediná chvíle, kdy jsem měl s angličtinou potiže. A stalo se to, že byl speciální den - všechny dèti, ale pouze děti, měly dostat zmrzlinu. Ale jen jeden kopeček. Takže jsme udělali frontu a každý dostal kopeček. A pak byla řada na mně. Aby vám to bylo jasné, uměl jsem $v$ angličtině jen pár slov: matka, otec, sestra, bratr, ano, ne. Ten člověk se mě ptal: ,Chcě́ nějakou...?' Ǩekl: ,Měl jsi nějakou zmrzlinu?' Protože jsme mohli dostat jenom jeden kopeček. A já jsem řekl: ,Ano, ano, ano!' Myslel jsem, že řekl: ,Chcě̌ trochu zmrzliny?'Tak jsem řekl: „Ano!' Takže on řekl: „Ne, už nemůžeš dostat dalši zmrzlinu.' Byl jsem úplně zničený, to si ani neumite predstavit. To byla asi jediná chvile, co si pamatuji, kdy jsem mèl problém s angličtinou.

Vite, malé děti se velmi rychle učí. Angličtina byla pravděpodobně první jazyk mé matky - ani čeština, ani němčina, protože musela chodit do školy. Takže, vite, hodně mi pomohla. Ale to vite, malé děti se velmi rychle přizpưsobí. Takže takhle nějak jsme se dostali do Jižní Afriky a byla to dobrá doba. Mưj otec byl ze všeho nejvíc umělcem. A maloval, miloval malování. Takže šest měsíců maloval, a když začalo docházet jídlo, sehnal si práci, šest měsíců pracoval a pak zase šest měsíců pracoval jako umělec. Ale byl velmi úspěšný umělec. Jeho díla jsou $v$ několika z hlavnich muzei v Evropě. Nakonec jsem tam vyrostl. Byl jsem typický chlapec, ale byl tu problém. Mé jméno se zdálo směšné - Kallik. Protože v Jižní Africe jste měli bud' anglické, nizozemské, nebo francouzské jméno, nic jiného. Takže Kallik bylo trochu směšné. Tak jsem se vzdělával a mým problémem bylo, že moje matka vždycky trvala na tom, abych byl dokonalý. Byl jsem Komenského... Komenský byl můj předek. Musel jsem skákat nejvýš, být nejlepši ve škole a, vite, v té době byla velmi nábožensky založená, takže jsem se musel držet Bible, což byl problém - k tomu se dostanu později. Takže jsem prostě musel vynikat. Řekla, že nesmím... že musím nastavit druhou tvár̆. Tak je to v Bibli. Když ti někdo ukřivdí,

\footnotetext{
${ }^{20}$ V Československu.
} 
nastavíš i druhou tvár. Nepereš se. Byl to docela problém, protože jsem byl dost velký, ale nastavoval jsem druhou tvář́. A ostatni malí chlapci mě strašně šikanovali. A pak mi jednoho dne četla Bibli, a co se stalo? Říkalo se tam, že silní musí vždy pomáhat slabým. Aha. Když mě někdo praštil, utekl jsem. Když někdo praštil někoho jiného, přišel jsem mu na pomoc. A než byste se nadáli, měl jsem malou partu kamarádů a byl její vůdce. A už nás nikdo nešikanoval. Tak jsem nakonec vyrostl. Jednou z nejlepšich věcí, co má matka udělala, bylo, že když mi bylo asi tak 14 let, 13 nebo 14 let, dala mě do školy. Jmenovala se Škola Edwarda VII. a byla to asi ta nejlepši škola v Johannesburgu. No, musím řict, že byla nejlepši, protože jsem tam šel. Ale byla to polovojenská škola, takže každé ponděli jsme nosili uniformy, pochodovali jsme sem a tam. A já tam dva roky docházel přes den - chodil jsem tam na vyučování a potom jsem šel domi̊. Ale potom jsem šel na internát a tam to bylo velmi př́isné. Bylo to jako v armádě. Zbožňoval jsem to. Byla tam pravidla, bylo tam jídlo, museli jste se věnovat sportu, museli jste se naučit tancovat, museli jste se naučit zpívat. A ty tři roky byly jedněmi z nejšt’astnějšich v mém životě. A když jsem maturoval, už jsem nebyl ,trochu divný;, byl jsem Angličan. Byl jsem ten nejlepší. A věděl jsem, že jsem nejlepši, nikdo mi to nemusel ř́kat. Dařilo se mi velmi dobře. Byl jsem nejlepši ve třídě. V posledním ročníku jsem byl poručikem a výsledkem toho bylo, že jsem vedl rotu čtyřiceti chlapcü. A jak jsem řikal, velmi jsem si to užil.“

Gerta Figulusová-Kalliková znovu navštívila Československo v roce 1958 na pozvání československé vlády u prŕíležitosti 300. výročí vydání pedagogických spisů Komenského Opera didactica omnia. Tyto oslavy Komenského byly pojaty velkolepě (byla uspořádána velká výstava v Pedagogickém muzeu J. A. Komenského nebo mezinárodní konference $\mathrm{s}$ účastí mezinárodních komeniologů včetně prof. Klause Schallera ${ }^{21}$, a proto i př́tomnost Gerty Kallikové dodala oslavám velkého lesku a důležitosti.

Naposledy Gerta navštívila Českou republiku u příležitosti oslav 400. výročí narození J. A. Komenského v březnu 1992. Ministerstvo školství, mládeže a tělovýchovy dalo Pedagogickému muzeu J. A. Komenského úkol, aby se o potomkyni Komenského staralo během cestování po českých zemích - do všech míst spojených s životem Komenského. Doprovázel ji tehdejší ředitel Pedagogického muzea J. A. Komenského Tomáš Pasák a odborná pracovnice Nad'a Potočná. ${ }^{22}$ S Tomášem Pasákem se dohodla na budoucí spolupráci v rámci výstavní činnosti. V Muzeu J. A. Komenského v Uherském Brodě paní Kalliková otevřela (společně s prezidentem Václavem Havlem a vedením muzea) novou stálou expozici J. A. Komenský lidstvu dne 28. března 1992. Do muzejní pamětní knihy

\footnotetext{
${ }^{21}$ Klaus Schaller se po padesáti letech od této akce zúčastnil další konference, a to v roce 2007 společně se synem Gerty Janem F. Kallikem.

22 POTOČNÁ, Nad’a, 2004. Oslavy 400. výročí narození J. A. Komenského v Pedagogickém muzeu J. A. Komenského. In: Sborník př́spěvků o průběhu oslav 400. výroči narozeni J. A. Komenského. Praha: Pedagogické muzeum J. A. Komenského, s. 54-57.
} 
napsala tato slova: „Po mnoha návštěvách v Uherském Brodě je vidno, že Uherský Brod roste a hloubi se v kráse a milosti. Gerta V. Kalliková Figulusová."23

Po celou dobu jí doprovázela také její vnučka Michelle Solly, dcera Jarmily Daniely Kallikové (1944). Před př́ijezdem do Prahy se zúčastnila i oslav Komenského v Berlíně (včetně odhalení sochy Komenského sochaře Josefa Vajceho) v Komenského zahradě v Berlíně-Rixdorfu). V Praze byla přijata prezidentem Václavem Havlem, Alexandrem Dubčekem a rektorem Univerzity Karlovy Radimem Paloušem a byla jí předána oficiální medaile Československého výboru pro oslavy 400. výroči narozeni Komenského Jozefem Mikloškem (1939). Medaili udělovalo Federální shromáždění České a Slovenské Federativní republiky. Po pražské mezinárodní konferenci navštívila nejen Muzeum J. A. Komenského v Uherském Brodě, ale i Brandýs nad Orlicí, Kunvald, Přerov, Nivnici, Komňu, Kyjov a Bratislavu. Při setkáních na různých místech republiky i sdělovacím prostředkům se nejednou vyznala $\mathrm{k}$ lásce $\mathrm{k}$ českému národu a jeho historii. Při návštěvě přerovského Muzea Komenského o sobě řekla: „Mám jihoafrické občanství, jsem občankou USA, ale citím se být i občankou Československa. Čím tedy jsem? Záleži na tom? At’ žijeme kdekoli, musíme být především lidmi. Tak to chtěl i Komenský!“" 24 Je jisté, že návštěva paní Kallikové přispěla k důstojnému charakteru oslav 400. výročí narození J. A. Komenského.

Během svého života v USA se stále zajímala o všechno, co se vztahovalo k Československu, včetně nových poznatků v oblasti komeniologie. Stále se cítila československou občankou. Také velmi pozitivně vnímala politickou změnu, která nastala po roku 1989. S osobní radostí vnímala polistopadový vývoj a znovuzískání svobody. Při setkávání s českými občany připomínala mravní a kulturní sílu českého lidu, kterou neztratili ani v období třicetileté války (1618-1648) ani v čase totalitních režimů. Se svými dětmi a vnoučaty se též zúčastnila komeniologické konference, která se konala u př́ležitosti 400. jubilea Komenského v Los Angeles (1992).

Zemřela ve věku 84 let. Na úmrtním oznámení byla označena jako „Dcera České republiky, potomkyně Jana Amose Komenského, Učitele národü“.

Díky rodině Vaňkových objevené dopisy obohatily seznam již vědcům známé Komenského korespondence. Také dokumentární film z roku 2019 natočený v domě Jana F. Kallika se stal svědectvím o životě jeho předků. Korespondence rodiny Figulových rovněž dokazuje, jak se otec J. V. Figulus snažil, aby jeho dcera získala vzdělání v českých zemích a naučila se českému jazyku. Gerta Figulusová se tak stala poslední potomkyní Komenského, která uměla česky a používala češtinu i při výchově svých dvou dětí - Jana a Jarmily. Jarmila zůstala

\footnotetext{
${ }^{23}$ Fotografie jejího rukopisu byla publikována v katalogu expozice $J$. A. Komenský lidstvu; uspořádala Markéta Husková (Pánková), Uherský Brod 1992, s. 4. Autorka př́spěvku se osobně s Gertou Kallikovou setkala v Uherském Brodě; vzpomíná na ni jako na ušlechtilou dámu s laskavou tvář́ (ze zdravotních důvodů seděla na vozíku, doprovázela ji její vnučka). Byla obklopena mnoha lidmi, kteří se chtěli dostat do její blízkosti, aby jí vyslovili úctu.

${ }^{24}$ HÝBL, František, 1991. Po stopách potomků J. A. Komenského z rodu Figulusů, SCetH XXI, č. 43, s. 7-27; Týž: Osmdesátiny G. V. L. Kallikové-Figulusové, SCetH XXIII, 1993, č. 50, s. 109-10; Týž: Zemřela Gerta Kalliková-Figulusová, SCetH XXVII, 1997, č. 57-58, s. 258-259.
} 
v Čechách. ${ }^{25}$ Jan, který absolvoval převážnou část vzdělání v amerických školách, kde se svou matkou Gertou po válce žil, český jazyk v současné době při hovoru nepoužívá. Zná jej pasivně a své děti již ke znalosti českého jazyka nevedl. Jak sám sdělil: (...) „český jazyk je těžký, sám jsem se jej snažil doučit pomocí čtení Bible. Gramatiku neumím vi̊bec.“

Generace 20. a 21. století sledovala životní dráhu rodiny Figulů a Jablonských, př́mých potomků po Petru Figulovi a Alžbětě Komenské, dceři Komenského. Jak z rodokmenu vyplývá, Gertin otec J. V. Figulus byl z osmé generace Komenského. Rod se záhy rozvětvil v Německu na dvě rodiny: na rodinu Jablonských a Figulů. O Jablonských psali v časopise Monatshefte der Comenius Gesselschaft v r. 1894, že ještě žijí, ale další zprávy již nejsou. ${ }^{26}$ Vznikaly a zpracovávají se články a knihy o potomcích, stále preciznější rodokmeny Komenského, nebot’ český národ byl vždy spojený s odkazem J. A. Komenského a jeho potomků. Už se narodili další potomci, z nichž nejmladší je vnuk Jana F. Kallika - James Frederick Peter Kallik, který se narodil 23. září 2010 (dvanáctá generace). O Komenském jako svém nejslavnějším předkovi ví, ale jak sám ř́ká: „V Americe o Komenském nic nevědí, ani se o něm na školách neuči. “ Stejné zkušenosti potvrdil také další vnuk Jana Kallika Steven Miketta ${ }^{27}$ (2004), se kterým byl rovněž natočen rozhovor před kamerou Petra Šolara. V roce 2020 probíhaly Národní oslavy J. A. Komenského u př́ležitosti 350. výročí jeho úmrtí. Ve stejném duchu, jako před 100 lety, český národ připomínal aktuální odkaz Učitele národů. ${ }^{28}$ Při oficiálním zahájení těchto oslav v Pantheonu Historické budovy Národního muzea v Praze dne 2. záŕí 2019, za účasti ministrů a zástupců univerzit a kulturních institucí, přečetla M. Pánková zdravici Jana F. Kallika, ve které připomínal jeho silný vztah ke svému předkovi - J. A. Komenskému - a nabádal společnost $\mathrm{k}$ tomu, aby si více připomínala křest’anské hodnoty, které nám Komenský zprostředkovává ve svém díle. ${ }^{29}$

\footnotetext{
${ }^{25}$ Není známo, zda dosud žije.

${ }^{26}$ POLAVSKÝ, Arnošt, 1928. J. V. Figulus a jeho dobrodružství, Praha, s. 156.

${ }^{27}$ Syn dcery Jana F. Kallika, paní Lynette Miketta.

28 Všechny aktivity jsou vedeny na speciálním webu Comenius350.cz - koordinovaném Národním pedagogickým muzeem a knihovnou J. A. Komenského.

${ }^{29}$ Zdravice je uložena v NPMK.
} 


\section{Obrazová př́loha}

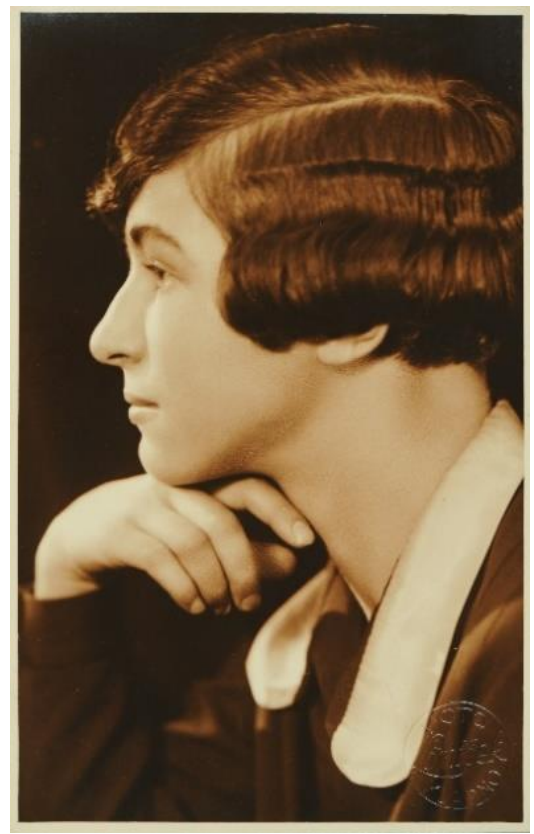

Gerta Figulusová v osmnácti

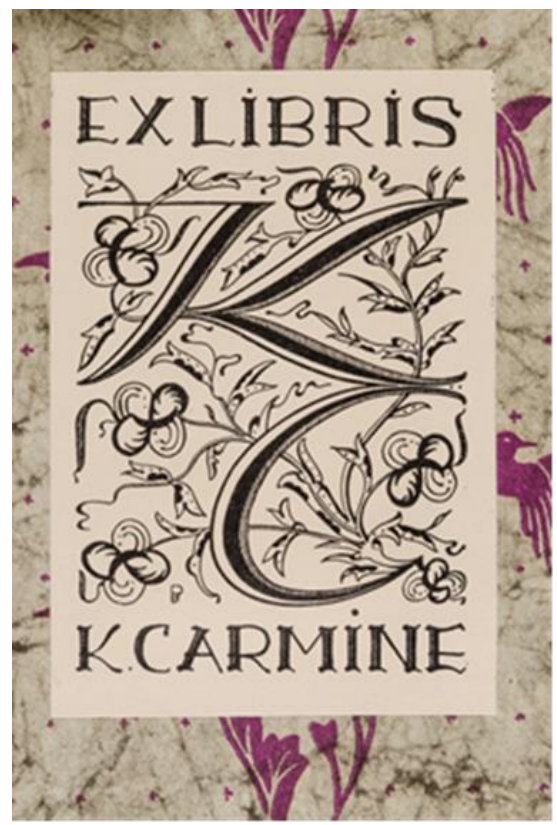

Ex libris Karla Carmineho. letech. Archiv rodiny Vaňkových.

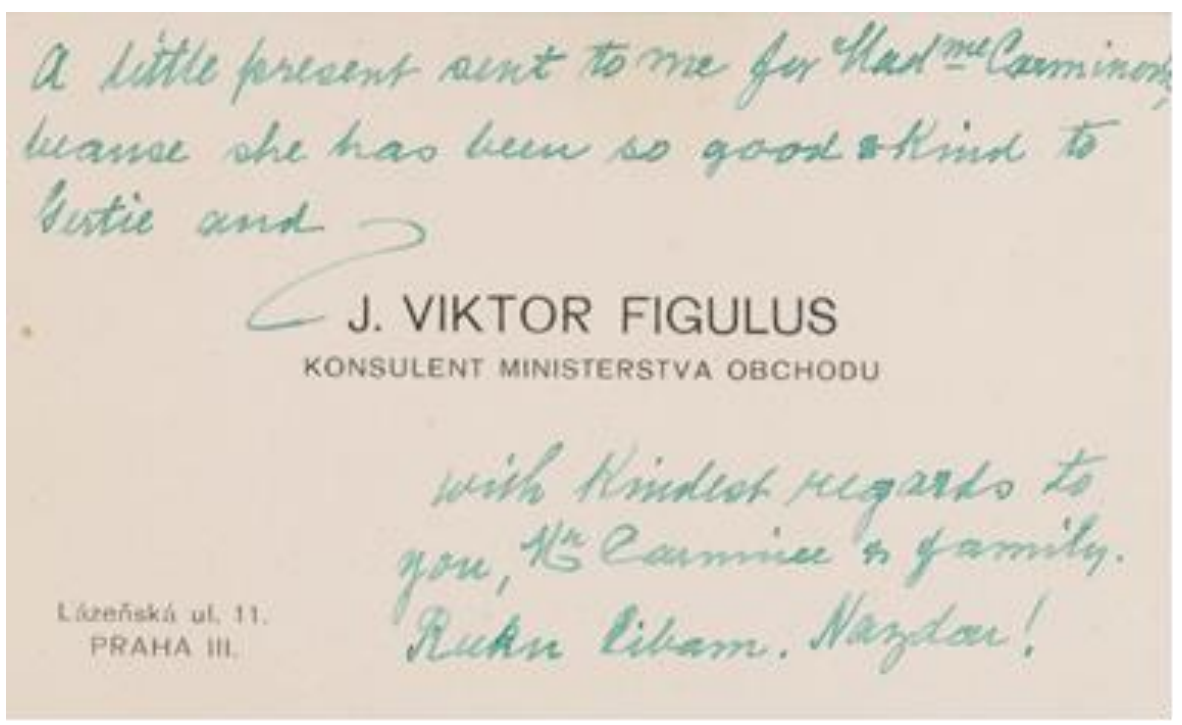

Vizitka J. V. Figula. Archiv rodiny Vaňkových. 


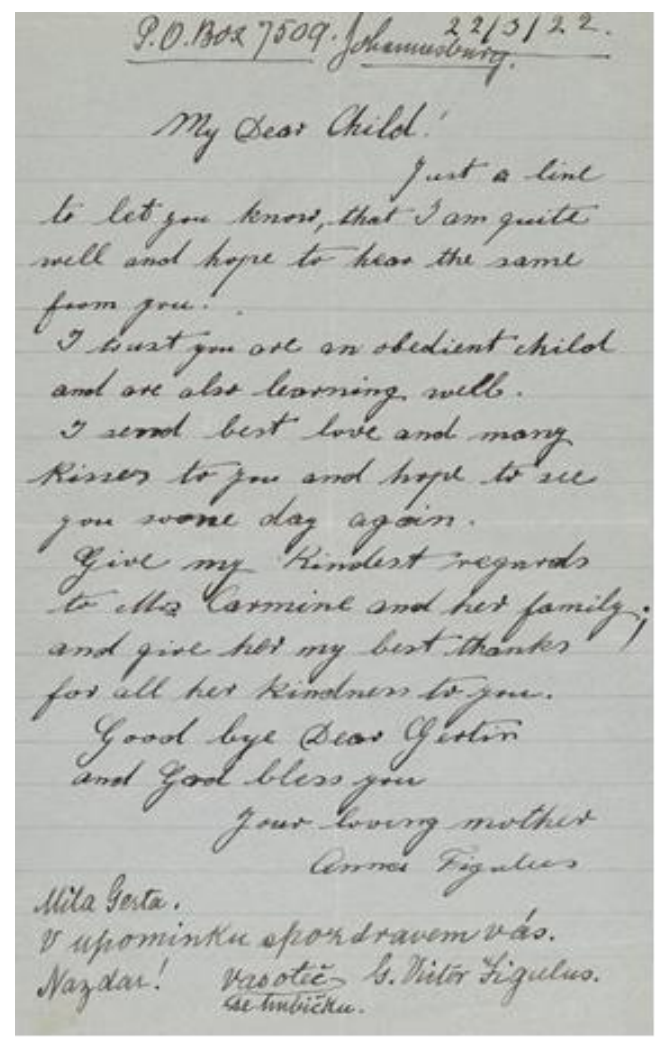

ardea near Teneriffe, Canany Istuna 21. $/ 12 / 21$.

UNION-CASTLE LINE

Dear Nos Garmine.

Hy shoughts and heast have remainat to Irague and it is shesefore not to be wonderen, shat of mish to connmuni ente mith the Kind preople there, 9 had to leanc behiced, as ofters as an apportunity affers.

I mich to esperess to yon my mosh heartfelt thantes for the many tinin'neases shown me aud my girl, the latter of which, of feel sure, mill continne even during my absence. 9 thunte you for she great interest you are taking in Gertic and Itrues you will still Heep a Kinoly and matchful eys on her. As munt mish her general malbing as also mith
Dopis matky Anny Gertě Figulusové z 22. března 1922. Archiv rodiny Vaňkových.

Dopis J. V. Figula pro paní Carmineovou, opatrovnici Gerty ze dne 21. 12. 1921. Archiv rodiny Vaňkových. Překlad dopisu J. V. Figula pro paní Carmineovou:

U moře na Tenerife, Kanárské ostrovy.

21. 12.1921

\section{UNION-CASTLE LINE}

Milá pani Carmine.

Myšlenkami a srdcem jsem stále v Praze, a není divu, že si přjeji být co nejčastěji ve spojení s těmi laskavými lidmi, které jsem musel opustit.

Rád bych Vám vyjádřil své nejsrdečnější diky za všechnu laskavost, kterou jste mně a mé holčičce prokázala a jsem si jist, že vtom budete pokračovat i po mém odjezdu.

Děkuji Vám, že se o Gertie staráte s takovým zájmem, a věrím, že na ni budete $i$ nadále dohližet starostlivě a vlídně. A to po stránce všeobecného prospěchu, i co se týče vyučování. 


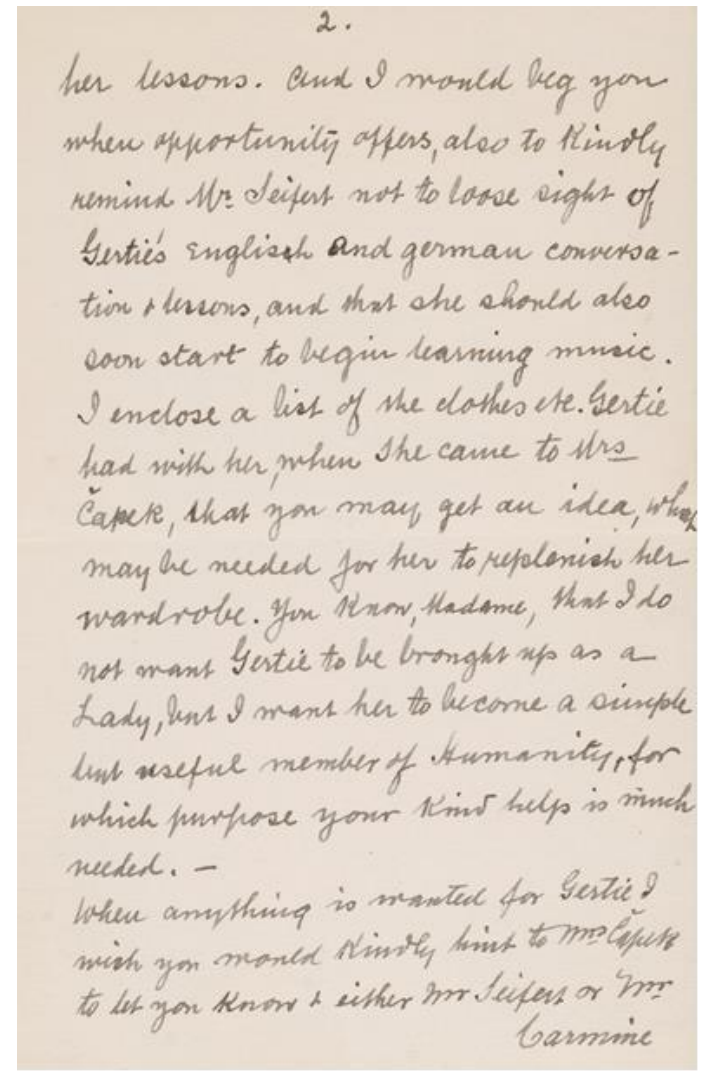

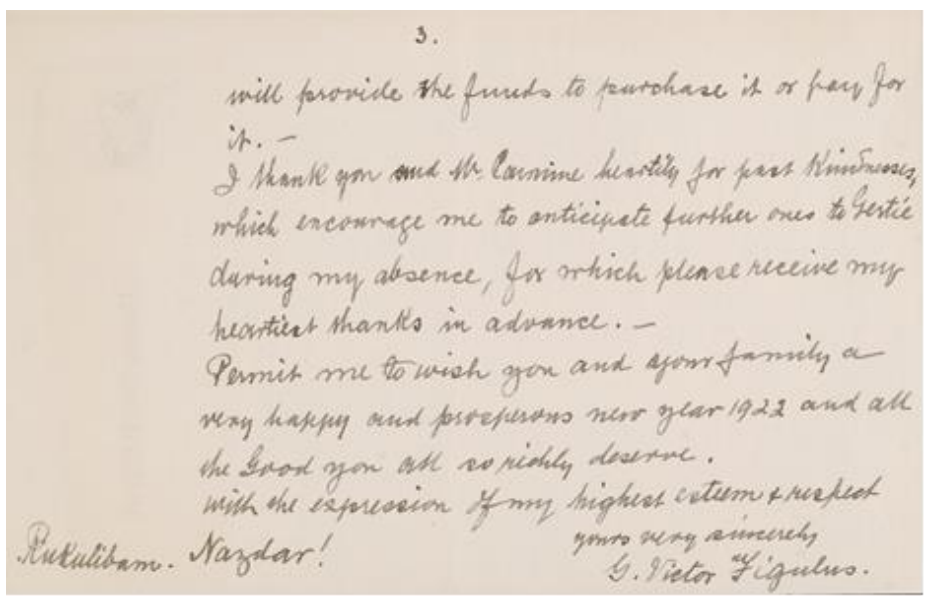

Velmi bych Vás prosil, abyste, až bude př́ležitost, laskavě připomněla panu Seifertovi, aby dál dohližel na Gertinu anglickou a německou konverzaci a hodiny, a také že by se brzy méla začit učit hudbě. Přikládám seznam oblečeni a podobně, které měla Gerta ssebou, když přijela k paní Čapkové, mohla byste si z něj udělat predstavu, co Gertie potřebuje doplnit do šatniku. Vy vite, madam, že nechci aby Gertie byla vychovávaná jako panička. Přeji si, aby z ní byla prostá, ale užitečná součást lidstva, a v tom mi můžete být velmi nápomocná. Kdyby Gertie cokoli potřebovala, prosím, sdělte laskavě pani Čapkové, aby Vám to rekla, a také pan Seifert nebo pan Carmine zajistí prostředky na pořizeni těch věcí, nebo je zaplatí. Srdečně Vám i panu Carmine děkuji za laskavě prokázané služby. Jak předpokládám, budete v tom pokračovat $i$ vdobě mé neprítomnosti, a za to, prosím, prijiměte předem mé nejsrdečnější diky.

Dovolte mi, abych popřál Vám i Vaší rodině štastný a prriznivý nový rok 1922 a jen to nejlepší, jak si všichni tak bohatě zasluhujete. S nejvyššim uznáním a úctou

Váš oddaný

J. Victor Figulus.

Rukulibam. Nazdar! 